\title{
El Partido Comunista de Chile y la empresa periodística de El Siglo: apuntes sobre sus orígenes y desarrollo
}

\author{
Alfonso Salgado Muñoz ${ }^{1}$ \\ Recibido: 26 de noviembre de 2018 - Aprobado: 14 de enero de 2019
}

\begin{abstract}
Resumen
En este artículo se analizan, desde una perspectiva económica, dos momentos importantes en la historia temprana del diario El Siglo, órgano oficial del Partido Comunista de Chile. En primer lugar, se examina la adquisición de una céntrica propiedad en Moneda 716 y el montaje de un eficiente taller de imprenta, en el cual se editó el periódico durante sus primeros años. En segundo lugar, se analiza la venta del inmueble y el desarme y traslado de la maquinaria de imprenta, una vez desatada la persecución anticomunista de Gabriel González Videla. No obstante las circunstancias caóticas que pusieron fin a la primera época del diario, el dinero de la venta de Moneda 716 le permitió al Partido Comunista adquirir una nueva propiedad, en Lira 363, donde se rearmó el taller de imprenta -renombrado Imprenta Horizonte- y desde donde se comenzó a editar nuevamente El Siglo unos años después.
\end{abstract}

Palabras clave: Partido Comunista, periódico, prensa, imprenta

\section{The Communist Party in Chile and the Newspaper Company El Siglo: Notes on Its Origins and Development}

\begin{abstract}
This article analyzes, from an economic perspective, two important moments in the early history of the newspaper E/ Siglo, official newspaper of the Communist Party in Chile. It first looks at the acquisition of a centrally-located property at Moneda 716 and the construction of an efficient printing workshop where the newspaper was edited during its early years. In the second place, it analyzes the sale of the property and subsequent disassembly and transfer of the printer machinery once President Gabriel González Videla unleashed his anti-Communist persecution. Notwithstanding the chaotic circumstances that brought the newspaper's early days to an end, the money from the sale of Moneda 716 allowed
\end{abstract}

Chileno. Doctor en Historia, Columbia University, Estados Unidos. Investigador Postdoctoral, Escuela de Historia, Facultad de Ciencias Sociales e Historia, Universidad Diego Portales, Chile. E-mail: alfonso.salgado@mail.udp.cl 
the Communist Party to purchase a new property located at Lira 363, where the printing workshop was reassembled -and renamed Imprenta Horizonte- and where El Siglo began to be edited again a few years later.

Keywords: Communist Party, newspaper, press, printing

En este artículo estudio aspectos poco conocidos de la primera época del periódico El Siglo, órgano del Partido Comunista de Chile (PCCH). Su historia puede dividirse en cuatro épocas o etapas. La primera de ellas, en la que se centra este artículo, va de agosto de 1940 a julio de 1948, cuando el periódico aparecía diariamente. La segunda, de octubre de 1952 a septiembre de 1973, también de frecuencia diaria. La tercera se caracterizó por su condición de ilegalidad y por su consecuente irregularidad, y tuvo lugar durante la dictadura de Augusto Pinochet. La cuarta y última época comenzó en septiembre de 1989, cuando el periódico logró publicarse nuevamente de manera legal y con regularidad, aunque ahora semanalmente.

La contribución de este texto se centra en dos coyunturas claves de la primera época: la que dio origen al periódico, en agosto de 1940, y la que llevó a su desaparición, transitoria, en julio de 1948. Rastreo, primero, las operaciones comerciales a través de las cuales los comunistas chilenos adquirieron una espaciosa propiedad y montaron un taller de imprenta en Moneda 716, sentando los cimientos de la empresa periodística de El Siglo. Se documenta, después, el hostigamiento político durante el Gobierno de Gabriel González Videla y los problemas económicos que este acarreó, fenómenos que, en conjunto, llevaron a que los comunistas decidieran dejar de editar el periódico, vender el inmueble y desmontar el taller de imprenta. No obstante su abrupto fin, esta primera época de vida de E/ Siglo tuvo consecuencias importantes en el desarrollo de la prensa comunista en Chile, que van más allá del periodo en cuestión. Como se demuestra en este artículo, la sustantiva inversión de capital inicial, que permitió adquirir Moneda 716 y montar un taller de imprenta relativamente moderno, siguió dando réditos aun después de julio de 1948. La venta de Moneda 716, en noviembre de 1948, generó una significativa cantidad de dinero, parte del cual se utilizó para comprar una nueva propiedad, en Lira 363. Allí el PCCH eventualmente rearmó su taller, que pasó a conocerse bajo el nombre de Imprenta Horizonte, y, en las postrimerías del Gobierno de González Videla, publicó nuevamente El Siglo.

Este artículo forma parte de un proyecto de investigación más amplio, que analiza la dimensión empresarial de la prensa de izquierda en las décadas de 1930 y 1940. Durante los años que cubre este proyecto, el PCCH se plegó al modelo comercial e informativo del periodismo moderno, aun cuando en términos retóricos se mantuviese fiel a la tradición de autogestión y periodismo 
obrero de sus primeros años, rindiéndole continuos homenajes al tipógrafo, editor de periódicos y fundador del partido, Luis Emilio Recabarren. Los orígenes de esta transformación, aún escasamente comprendida, pueden datarse en la segunda mitad de los años treinta, cuando el PCCH adoptó la estrategia de los frentes populares para detener el avance del fascismo y buscó aliados para ser una alternativa real de gobierno. Fue precisamente en estos años, e inspirada por este viraje táctico, que la prensa comunista empezó a adoptar estrategias comerciales de financiamiento, incluyendo dosis importantes de avisaje, y a competir por capturar la atención de un público lector heterogéneo, no necesariamente militante, con el objeto de incidir en la opinión pública. Sin embargo, no fue sino hasta la aparición de El Siglo, en agosto de 1940, que el PCCH contó con un periódico de alcance propiamente nacional, capaz de llegar a un público masivo y competir, de igual a igual, con los principales periódicos del país. Como señaló orgulloso el órgano comunista al celebrar su segundo aniversario, en agosto de 1942, en solo dos años había pasado a ocupar "el segundo lugar en tiraje de todos los diarios de Chile" (El Siglo, 31-VIII-1942: 43).

Este proyecto ha sido concebido como una contribución tanto a la historia de la izquierda como al estudio del periodismo y de las comunicaciones en Chile. Contamos con un número no menor de investigaciones sobre el surgimiento de la prensa moderna en nuestro país, en las primeras décadas del siglo veinte (Bernedo y Arriagada, 2002; Couyoumdjian, 1998; Couyoumdjian et al., 2002; Ossandón y Santa Cruz, 2001 y 2005; Santa Cruz, 2015). Gracias a estas investigaciones, sabemos que todo diario de carácter masivo era, al mismo tiempo, y por necesidad, un proyecto periodístico y una empresa comercial. Sin embargo, cuando se trata de diarios como El Siglo, se les sigue concibiendo meramente como proyectos político-periodísticos. Los trabajos de los académicos que se han interesado por la prensa de izquierda permiten hacerse una buena idea de su discurso e impacto en la sociedad chilena, pero casi no examinan su administración y gestión (Acevedo, 2012; Bernedo, 2003; Dalmás, 2010; Donoso, 2016a y 2016b; Dooner, 1989; Errázuriz, 2013; Faure, 2017; Fernández-Niño, 2014; López, 2016; Loyola 2012; Moyano y Rivera, en prensa; Muñoz, 2015; Rivas, 2012; Rojas, 2012; Riquelme, 1986). Entre las excepciones que cabe destacar se cuenta el pionero e innovador trabajo de Guillermo Sunkel, quien presta cierta atención a las condiciones de producción de esta prensa, si bien su análisis es algo esquemático y, para el caso de $E$ I Siglo en particular, presenta ciertas imprecisiones. Haciéndose eco de la narrativa del PCCH, Sunkel sostiene que "el diario debe su nacimiento, en gran parte, a una campaña financiera de carácter nacional promovida por el partido" (2016: 104), lo que pondremos en duda en las páginas siguientes. Centrarse en el aspecto empresarial, prácticamente olvidado por los estudiosos, permitirá tener una mejor comprensión de las estructuras que 
condicionaron el surgimiento y desarrollo de la prensa de izquierda en Chile y de los desafíos que dirigentes, editores y periodistas debieron enfrentar.

En lo que respecta a la investigación propiamente tal, este artículo se ha servido, entre otras fuentes, de la misma prensa comunista, en especial de los periódicos Frente Popular y El Siglo, cuyos ejemplares se encuentran en la Biblioteca Nacional de Chile; de informes y publicaciones partidarias de diversa naturaleza, consultados en la misma biblioteca; de documentación de la Internacional Comunista o Komintern, recopilada por Ulianova y Riquelme (2017); de informes desclasificados del Federal Bureau of Investigation (FBI), que se conservan en el National Archives and Records Administration (NARA), en Estados Unidos; y de informes desclasificados de la Central Intelligence Agency (CIA), disponibles en el sitio web de la misma institución. Además, se invirtió bastante tiempo en rastrear los negocios de la Sociedad Barra y Compañía Limitada, una sociedad colectiva de responsabilidad limitada a través de la cual el PCCH realizó la mayor parte de sus transacciones comerciales durante los años del Frente Popular, en el Archivo Judicial de Santiago (AJS) y en el Conservador de Bienes Raíces de Santiago (CBRS).

\section{Nacimiento de El Siglo}

El Siglo vio la luz el sábado 31 de agosto de 1940, certificando ante notario la emisión de 46.200 ejemplares, "los mil primeros de los cuales se apartaron y fueron declarados 'documentos históricos'" (El Siglo, 31-VIII1960: 2). Pero sus orígenes pueden datarse con bastante anterioridad. Al parecer, fue durante el X Congreso Nacional del PCCH, realizado en abril de 1938, que se discutió por primera vez la idea de adquirir una propiedad y montar una nueva imprenta, aunque de ello no quedó registro en la prensa partidaria ni en los informes publicados tras dicho congreso (cfr. González, 1938; y Escobar, 1939: 10). La idea solo tomó fuerza el año siguiente, cuando se lanzó una gran campaña de finanzas, que buscaba recolectar \$1.000.000 para dicho fin (Frente Popular, 28-IV-1939: 8-9; Escobar, 1939: 11-13). Es interesante notar, sin embargo, que la idea original era destinar dicha propiedad e imprenta a mejorar el periódico que el PCCH editaba en aquel momento, llamado Frente Popular, y que solo durante el transcurso de la campaña de finanzas se empezó a hablar de crear un nuevo periódico. Las primeras alusiones explícitas a El Siglo, con dicho nombre, datan de inicios de 1940, cuando se creía que su lanzamiento era inminente (v.gr., Frente Popular, 22-1-1940: 12).

La principal inversión del PCCH en este contexto fue la compra de una propiedad ubicada en la esquina de Moneda con Mac Iver, con frente a ambas calles. Allí, sobre un terreno de 31 metros de ancho por Moneda y 39 metros de largo por Mac Iver, se erigía una imponente casona de dos pisos, 
hoy desaparecida; una "lujosa mansión," en el decir de algunos (Vea, 15-XI1939). A la propiedad se le conoció con el nombre de Moneda 716, aunque tenía entradas por ambas calles. La entrada principal, la de la administración del nuevo diario, era la de Moneda; la de Mac Iver era utilizada por el taller de la imprenta. Antes de entrar en operaciones El Siglo, el partido debió realizar ciertas modificaciones a la casona en cuestión. La fachada casi no fue alterada. Se le agregó, eso sí, una vistosa estrella de cinco puntas, adornada con una hoz y un martillo, la cual lucía orgullosa sobre el techo del segundo piso, en la esquina de Moneda con Mac Iver, y que se alumbraba durante las noches. Al parecer, la misma estrella fue colocada unos años después sobre Teatinos 416, inmueble que empezó a arrendar el PCCH en 1958, tras la derogación de la Ley de Defensa de la Democracia. ${ }^{2}$ Las principales modificaciones realizadas a Moneda 716 tuvieron lugar en el patio interior de la casona, pues se debió cavar una fosa de varios metros y construir una base de concreto para la instalación de la rotativa y de otras maquinarias. La producción del diario ocupaba todo el primer piso. Allí se ubicaban las oficinas de administración y de redacción, y los diversos talleres (de linotipia, de estereotipia, etc.) que rodeaban a la rotativa, ubicada, como señalamos, en el patio interior de la casona. El segundo piso era ocupado por el Comité Central y el Comité Regional de Santiago, lo que facilitaba la comunicación entre los principales dirigentes del PCCH y los encargados de EI Siglo (Frente Popular, 21-XI-1939: 10 y 12).

El inmueble de Moneda 716, refaccionado por los comunistas, se puede apreciar en la Figura 1, publicada en Frente Popular a mediados de 1940. Dibujos y fotografías similares fueron publicados posteriormente en El Siglo, generalmente en fechas que conmemoraban el origen de dicho periódico. En cierto sentido, la posesión de este bien raíz se transformó en un motivo de orgullo para los comunistas. La retórica partidaria al respecto es elocuente: "En el corazón de Santiago, a escasas cinco cuadras de la Plaza de Armas, se yergue un edificio de dos pisos, portando como antorcha la estrella con la Hoz y el Martillo" (El Siglo, 31-VIII-1945: 1). Para sus adversarios, el edificio se convirtió en el símbolo del inusitado y amenazante poder que había logrado adquirir el comunismo en el país. "Ubicado en pleno centro comercial de la capital del país, a cinco cuadras de La Moneda, simbolizaba la preponderancia del comunismo dentro de las filas de la Izquierda extremista, cuyos hilos manejaba, y cuyo timón se aprestaba ya a dirigir sin disfraces, pasando por encima de sus aliados de siempre" (Estanquero, 18-IX-1948: 6).

Sobre el sorprendente hallazgo de una estrella similar en el Santiago de fines del siglo veinte, tal vez la misma a la cual hemos aludido arriba, véase el documental Estrella Roja, disponible en: https://vimeo.com/160976325, revisado el 8-XI-2018. Actualmente, dicha estrella se conserva en el Museo de la Memoria y los Derechos Humanos. Agradezco a Jorge Rojas Flores por llamar mi atención sobre esta coincidencia. 


\section{Figura 1}

Fachada del edificio del PCCH en Moneda 716

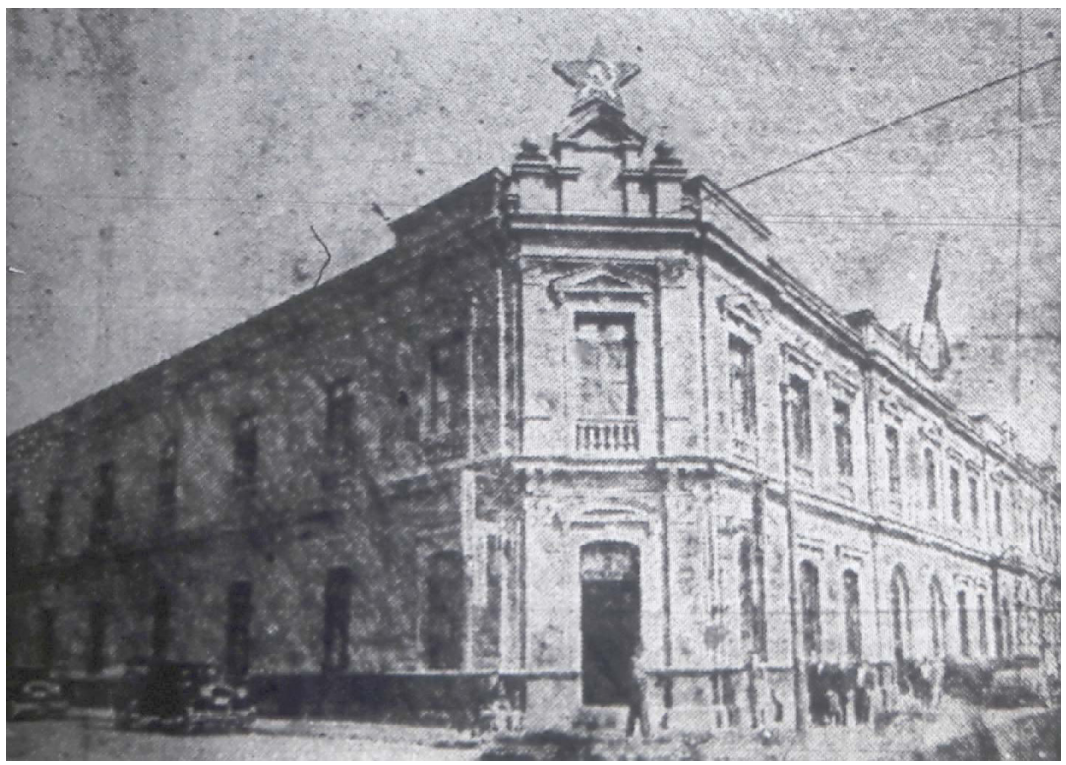

Fuente: Frente Popular, 1-V-1940: 12.

El PCCH adquirió la propiedad de Moneda 716 en 1940, a través de la sociedad colectiva de responsabilidad limitada que había formado en 1936 para sus negocios comerciales, la Sociedad Barra y Compañía Limitada. Pero la decisión de adquirir la propiedad y la mudanza ocurrió de hecho un año antes. La propiedad, que desde 1922 pertenecía a Washington Bascuñán, fue comprada por un comerciante de origen italiano llamado José Antonio Barchi el 17 de julio de 1939, por \$965.000, ${ }^{3}$ y fue éste quien se la vendió posteriormente a la Sociedad Barra y Compañía Limitada, el 12 de septiembre de 1940, por \$1.100.000. ${ }^{4}$ La naturaleza del acuerdo entre Barchi y la Sociedad Barra y Compañía Limitada no está del todo clara. Sin embargo, es evidente que existía un acuerdo, al menos de palabra, ya en julio de 1939, cuando Barchi compró la propiedad, pues el PCCH anunció la adquisición de la misma unos días después y empezó rápidamente a realizar las modificaciones al edificio reseñadas en el párrafo anterior (Frente Popular, 5-VIII-1939: 7; Qué Hubo, 21-XI-1939: 7). De hecho, la imprenta empezó a operar a

3 AJS, notario Luis Azócar Álvarez, 17-VII-1939, f. 641, núm. 157, "Compraventa: Barchi, José a Bascuñán, Washington".

4 AJS, notario Luis Azócar Álvarez, 12-IX-1940, f. 657, núm. 243, "Compraventa: Barra y Cía. Ltda. a Barchi, José Antonio". 
comienzos de 1940, editando primero Frente Popular, varios meses antes de la transacción por medio de la cual la Sociedad Barra y Compañía Limitada se hizo definitivamente de la propiedad, el 12 de septiembre de $1940 .{ }^{5}$

La ubicación privilegiada de la propiedad, "en pleno corazón de la ciudad que fundara don Pedro Valdivia" (Ravines, 1952: 435), contribuyó, por un lado, a prestigiar al PCCH ante la opinión pública chilena y, por otro lado, a que esta no perdiera su valor a medida que transcurría el tiempo. Muy por el contrario, la propiedad de Moneda 716 se valorizó significativamente en los años siguientes. Ya en 1943 el PCCH rechazó una oferta de compraventa de $\$ 4.000 .000$, aunque al parecer la oferta incluía tanto la propiedad como la imprenta. ${ }^{6}$ Al momento de vender la propiedad, en noviembre de 1948, lo hizo por $\$ 10.000 .000$, es decir nueve veces el precio de compra de 1940 y más de diez veces el de 1939.7 Aún tomando en consideración la inflación galopante de aquellos años, la ganancia que el PCCH obtuvo con su venta fue significativa, superior a los $\$ 6.000 .000$, como se aprecia en el Cuadro 1. Este cuadro incluye información concerniente al precio de compra de 1939 (ganancia de \$6.255.376) y al de 1940 (ganancia de \$6.033.376). Es probable que la propiedad hubiese sido vendida aún a mayor precio de no haber estado el PCCH apurado en venderla, como se explicará más adelante cuando abordemos la persecución anticomunista de Gabriel González Videla y el abrupto fin de la primera época de El Siglo.

5 Un hecho ocurrido entre la compraventa de julio de 1939 y la de septiembre de 1940, que ayuda a entender mejor estos sucesos, ocurrió en enero de 1940, cuando se modificó la Sociedad Barra y Compañía Limitada y se aumentó su capital de $\$ 180.000$ a $\$ 520.000$. En dicha ocasión, entraron a la Sociedad los principales dirigentes del PCCH, Carlos Contreras Labarca y Elías Lafertte, y los futuros encargados de El Siglo, Raúl Barra Silva y Jorge Jiles. AJS, notario Luis Azócar Álvarez, 1-III-1940, f. 72, núm. 28 "Modificación de Sociedad y Aumento de Capital: Barra y Compañía Ltda.".

6 Federal Bureau of Investigation, 16-I-1945, "El Siglo," en NARA, Record Group 59, Decimal File 1945-49, Box 5355.

7 AJS, notario Javier Echeverría Vial, 18-XI-1948, f. 1021, núm. 419 "Compraventa: Larraín A., Mario a Barra y Cía. Ltda.". 


\section{Cuadro 1}

Valorización de Moneda 716

\begin{tabular}{|c|c|c|c|c|c|c|}
\hline AÑO & INFLACION & $\begin{array}{c}\text { COMPRA } \\
1939\end{array}$ & $\begin{array}{c}\text { COMPRA } \\
1940\end{array}$ & VENTA 1948 & $\begin{array}{c}\text { GANANCIA } \\
1939\end{array}$ & $\begin{array}{c}\text { GANANCIA } \\
1940\end{array}$ \\
\hline 1939 & $7.61 \%$ & $\$ 965.000$ & & & & \\
\hline 1940 & $9.10 \%$ & $\$ 1.038 .437$ & $\$ 1.100 .000$ & & & \\
\hline 1941 & $23.14 \%$ & $\$ 1.132 .934$ & $\$ 1.200 .100$ & & & \\
\hline 1942 & $25.52 \%$ & $\$ 1.395 .095$ & $\$ 1.477 .803$ & & & \\
\hline 1943 & $7.83 \%$ & $\$ 1.751 .123$ & $\$ 1.854 .939$ & & & \\
\hline 1944 & $15.00 \%$ & $\$ 1.888 .236$ & $\$ 2.000 .180$ & & & \\
\hline 1945 & $7.71 \%$ & $\$ 2.171 .472$ & $\$ 2.300 .207$ & & & \\
\hline 1946 & $30.08 \%$ & $\$ 2.338 .892$ & $\$ 2.477 .553$ & & & \\
\hline 1947 & $23.08 \%$ & $\$ 3.042 .431$ & $\$ 3.222 .801$ & & & \\
\hline 1948 & $16.82 \%$ & $\$ 3.744 .624$ & $\$ 3.966 .624$ & $\$ 10.000 .000$ & $\$ 6.255 .376$ & $\$ 6.033 .376$ \\
\hline
\end{tabular}

Fuente: Elaboración propia.

Si bien la compra de Moneda 716 fue la principal inversión del PCCH en el tránsito de la década del treinta a la del cuarenta, el establecimiento de la imprenta tuvo un costo aún mayor, de sumarse la rotativa, las linotipias, la titulera y toda la maquinaria anexa. El objetivo del partido era montar una imprenta totalmente nueva, de altos estándares de calidad técnica, destinando la antigua a otros quehaceres. El costo total de la imprenta es difícil de determinar con certeza, pues las máquinas fueron compradas a distintos vendedores, en distintos momentos, pero fue de la magnitud de "un millón quinientos mil pesos," para citar la cifra dada por el dirigente comunista Andrés Escobar ante el Comité Ejecutivo de Komintern, en marzo de 1941 (citado en Ulianova y Riquelme, 2017: 721).

Uno de los costos más altos parece haber sido el de la rotativa, una máquina de imprimir periódicos que, mediante un movimiento rotatorio continuado, producía ejemplares a gran velocidad. Algunas fuentes hablan de $\$ 200.000$; otras de $\$ 250.000 .{ }^{8}$ En cualquiera de los casos, se trataba de un buen precio, ventajoso para los compradores. La transacción fue posible gracias a la intervención del presidente de la República, Pedro Aguirre Cerda, quien hizo de intermediario entre el PCCH y la administración de La Nación, dueña de la rotativa en cuestión, y quien además ayudó a sus aliados

8 cfr. El Siglo, 31-VIII-1960: 8; Central Intelligence Agency, 15-IX-1948, "Disposition of Property of El Siglo, Communist Newspaper," General CIA Records, consultado en: https:// www.cia.gov/ library/readingroom/docs/CIA-RDP82-00457R001801030007-5.pdf, revisado el 10-XI-2018. 
a conseguirse un préstamo de la Caja Nacional de Ahorros para realizar la transacción (Ravines, 1952: 435; Varas, 2010: 45; El Siglo, 30-VIII-1970). La adquisición de esta rotativa, que tuvo lugar a fines de 1939, fue vital para el desarrollo de la prensa comunista en el país, pues se utilizó a lo largo de varias décadas, en diversas empresas, sobreviviendo incluso al brutal ataque contra la Imprenta Horizonte el 3 de abril de 1957, que "casi liquidó la querida maquinaria" (EI Siglo, 31-VIII-1960: 8).

Es posible describir con cierto detalle la rotativa, pues la prensa comunista le dedicó gran cantidad de líneas y fotografías a lo largo de los años; de hecho, era costumbre que las delegaciones sindicales de provincia que visitaban las oficinas del periódico se tomaran una fotografía con la rotativa. La máquina, fabricada en Alemania en 1922, constaba de dos cuerpos que funcionaban autónomamente, es decir, podía funcionar uno mientras el otro estaba pausado, o los dos simultáneamente. Cada uno de los cuerpos tenía la capacidad de producir 20.000 ejemplares por hora (de 32 páginas tamaño mercurio o 63 páginas tamaño tabloide), lo que daba una capacidad de tiraje total de 40.000 ejemplares por hora (del número de páginas y tamaño ya referido). Las impresiones podían realizarse en negro o a tres colores, bastando para ello ejecutar algunos retoques en las láminas de plomo. Durante el período aquí estudiado, El Siglo se imprimió, por regla en general, en negro, reservándose el uso del color para los suplementos dominicales, los cuales eran llamativos, tipo magazine (Frente Popular, 27-III-1940: 4; Qué Hubo, 23-III-1940: 8; El Siglo, 31-VIII-1960: 8; El Siglo, 30-VIII-1970; Varas, 2010: 45).

Además de la rotativa, el PCCH armó su nueva imprenta gracias a la adquisición de cinco linotipias, una titulera y una serie de aparatos de menor valor (laminadoras, fresadoras, etc.). No tenemos información exacta en lo que respecta al precio de estas máquinas, pero varias de ellas parecen haber sido compradas en Estados Unidos por el empresario cinematográfico y militante comunista Amador Pairoa. ${ }^{9}$ Los encargados del periódico tuvieron particular interés en adquirir una titulera -es decir, una linotipia especializada en la composición de los titulares- que les permitiera producir títulos de gran tamaño y variedad, con el objeto de atraer la atención del lector y lograr hacer de El Siglo un diario de masas. Jorge Jiles se expandió en ello en una entrevista, explicando que era "la única máquina de este modelo y de estos

9 Federal Bureau of Investigation, 16-I-1945, "El Siglo", en NARA, Record Group 59, Decimal File 1945-49, Box 5355. Si bien este informe no identifica a la maquinaria en cuestión, es probable que la titulera haya sido una de ellas. Dos razones me llevan a esta conclusión. Primero, porque sabemos que la rotativa -la máquina de mayor importancia- era de fabricación alemana y que esta había sido comprada a La Nación, en Chile. Segundo, porque sabemos que la titulera -una máquina de importancia, también- era una "All-Purpose Linotype", comúnmente fabricadas en Estados Unidos, y que era la única máquina de su tipo en Chile en aquel entonces. Sobre esto último, véase Frente Popular, 23-III-1940: 8. 
tipos que hay en Chile; hemos puesto un gran cuidado en la cuestión de los titulares" (Frente Popular, 23-VIII-1940: 8).

De sumarse los desembolsos realizados para la adquisición y refacción de Moneda 716 y para la instalación de la imprenta, el costo de total de la inversión comunista debe estimarse entre $\$ 2.500 .000$ y $\$ 3.000$.000. Diferentes cifras apuntan en dicho sentido. Por ejemplo, en el XI Congreso Nacional del PCCH, realizado en diciembre de 1939, se dice que "[l]a compra de la Casa y la Rotativa nos ha colocado en el compromiso de tener que pagar un mínimum de cincuenta mil pesos mensuales hasta llegar a los $\$ 2.700 .000$ que necesitamos aproximadamente, "aunque por "rotativa" parece aludirse al taller de imprenta en su conjunto (Escobar, 1939: 11). En marzo de 1941, el delegado chileno Andrés Escobar les explicó a los miembros del Comité Ejecutivo de Komintern que, si bien la propiedad costaba "un millón cincuenta mil pesos" y las maquinarias de la imprenta "un millón quinientos mil pesos," el costo total de la operación era de "cerca de tres millones de pesos" (citado en Ulianova y Riquelme, 2017: 721). Otras fuentes dan cifras distintas (EI Siglo, 31-VIII-1942: 43; El Siglo, 30-VIII-1970), pero creemos que nuestra estimación es relativamente confiable.

El sustantivo desembolso de dinero que esta operación conllevó parece haberse logrado, principalmente, sobre la base de créditos. Si bien es probable que una parte del dinero que se pagó al contado haya provenido de los fondos que poseía el PCCH o, como veremos más adelante, de Komintern, la Sociedad Barra y Compañía Limitada contrajo deudas que lo obligaban a "tener que pagar un mínimum de cincuenta mil pesos mensuales", para citar nuevamente los documentos del XI Congreso Nacional del PCCH (Escobar, 1939: 11). A esta cifra aludió también el primer director de El Siglo, Raúl Barra Silva, en noviembre de 1939, cuando explicó que la gran mayoría del dinero utilizado para la compra de Moneda 716 y de la imprenta "lo estamos debiendo a diferentes acreedores en compromisos que nos representan más 0 menos cincuenta mil pesos mensuales" (Frente Popular, 21-XI-1939: 10 y 12).

Quiénes eran estos acreedores y bajo qué condiciones hicieron estos préstamos no es fácil de determinar, con excepción de alguno que otro de los prestamistas. Luz Rivas de Serrano, por ejemplo, le facilitó $\$ 270.000$ a la Sociedad Barra y Compañía Limitada para la adquisición de Moneda 716, constituyendo hipoteca sobre dicha propiedad en garantía. ${ }^{10}$ Sabemos, igualmente, que el dinero utilizado para la adquisición de la rotativa fue facilitado por la Caja Nacional de Ahorros, gracias a la intercesión de Pedro Aguirre Cerda. Y sabemos, por último, que a mediados de los años cuarenta

10 AJS, notario Luis Azócar Álvarez, 12-IX-1940, f. 674, núm. 247, "Mutuo: Barra y Compañía Limitada a Rivas, Luz". 
la Sociedad Barra y Compañía Limitada había recibido préstamos no solo de la Caja Nacional de Ahorros, sino también de la Corporación de Fomento, el Banco Central y el Instituto de Crédito Industrial. ${ }^{11}$ Ahora bien, no sabemos cuándo estas instituciones empezaron a prestarle dinero a la Sociedad Barra y Compañía Limitada, si desde antes de la aparición del diario -como fue el caso de la Caja Nacional de Ahorros- o una vez que este estaba ya en circulación y la sociedad comercial de los comunistas se había demostrado capaz de cumplir sus compromisos.

Simpatizantes comunistas y aliados políticos parecen haber jugado un rol clave en la obtención de los créditos necesarios para la compra de Moneda 716 y la nueva imprenta. En sus controversiales pero documentadas memorias, el otrora comunista Eudocio Ravines, quien participó en algunas de estas operaciones, señala que, "gracias al apoyo de los amigos del comunismo y a la sombra benéfica de los hombres del Gobierno y de los corifeos del Partido Radical, se constituyó una empresa de más de cuatro millones de pesos chilenos" (Ravines, 1952: 435).

La pregunta que queda por responder es cómo la Sociedad Barra y Compañía Limitada logró cumplir sus compromisos crediticios. De creérsele al discurso público del PCCH, esto se habría logrado a través de las cotizaciones regulares de los militantes y de una serie de colectas y campañas extraordinarias, la primera y más famosa de las cuales se denominó "Campaña Pro Casa y Rotativa", que se basó en la emisión de bonos que iban desde los $\$ 0.20$ hasta los $\$ 1.000$ (Frente Popular, 28-IV-1939: 8-9; Frente Popular, 1-V-1940: 12-13). Esta y otras campañas no solo ayudaron a financiar El Siglo, sino también contribuyeron a que algunos lectores se identificaran fuertemente con el diario. Los editores estimulaban dicha identificación, refiriéndose a los que participaban en estas campañas como "amigos" de El Siglo o, en un registro más económico, "accionistas de nuestra empresa" (El Siglo, 31-VIII-1942: 43).

Ahora bien, la relevancia de estas campañas extraordinarias en las finanzas de El Siglo no debe sobreestimarse. Los montos recolectados a través de ellas no fueron los esperados. Como explicamos arriba, los compromisos crediticios asumidos por los administradores de El Siglo obligaban a sufragar mensualmente alrededor de $\$ 50.000$. La experiencia demostró que era imposible obtener dicho dinero solo con base en colectas y campañas extraordinarias. En el XI Congreso, realizado en diciembre de 1939, el PCCH informó: "Tenemos ya un déficit de más de $\$ 30.000$ y en enero necesitaremos \$150.000" (Escobar, 1939: 12). Voces de alarma siguieron escuchándose en

11 Federal Bureau of Investigation, 16-I-1945, "El Siglo," en NARA, Record Group 59, Decimal File 1945-49, Box 5355. 
los meses siguientes. En abril de 1940, un pleno del Comité Central explicó que era imperativo recolectar $\$ 200.000$ en el mes de mayo para cumplir los apremiantes compromisos económicos que había conllevado la compra de Moneda 716 y de la imprenta (Frente Popular, 1-V-1940: 12-13). Según cifras entregadas por Andrés Escobar al Comité Ejecutivo del Komintern en marzo de 1941, "[l]a campaña por la recolección de dinero para dar cumplimiento a estas obligaciones contraídas por nuestro P[artido] en dos años y seis meses, ha dado $\$ 547.695,93$, suma que ha sido abonada a la deuda" (citado en Ulianova y Riquelme, 2017: 721). En otras palabras, las colectas y campañas extraordinarias alcanzaron a cubrir solo una fracción de los costos de Moneda 716 y de la imprenta.

Al parecer, las deudas contraídas en la compra de Moneda 716 y en la instalación de la imprenta terminaron de pagarse varios años después. En el quinto aniversario de El Siglo, celebrado el 31 de agosto de 1945, los encargados recordaron los compromisos contraídos antes de la aparición del periódico y agregaron: "Hoy día, la Empresa ha cancelado casi totalmente las deudas pendientes, ha adquirido tres linotipias más y ha montado un taller de obra" (EI Siglo, 31-VIII-1945: 1). Como se desprende de esta cita, los administradores del periódico continuaron constantemente invirtiendo dinero en la adquisición de maquinaria para la imprenta, por lo que es probable que la deuda original se hubiese saldado antes de habérsele considerado una prioridad. Del detalle de estas y otras transacciones comerciales nos da una idea la documentación notarial. ${ }^{12}$ Por lo general, la Sociedad Barra y Compañía Limitada pagaba una parte del precio de compraventa al contado (un tercio o la mitad del mismo) y se comprometía a pagar el saldo restante en cuotas mensuales, sobre la base de letras de cambio con vencimientos escalonados. La frecuencia de estas transacciones obligaba a la administración del periódico a hacerse cargo, mes a mes, no solo de los gastos operacionales de la imprenta y de las deudas contraídas al momento de la instalación de la misma, sino también de un número no menor de letras de cambios vinculadas a la adquisición de nuevas linotipias, prensas, etc.

Es probable que otra parte de las deudas contraídas en el proceso de adquisición de Moneda 716 y de la imprenta haya sido saldada con las ganancias obtenidas gracias a la publicación del mismo periódico, en los años

12 Véase, por ejemplo, las siguientes escrituras públicas en AJS, notario Luis Azócar Álvarez: 21-VI-1945, f. 953, núm. 379 "Compraventa: Barra y Cía. Limitada a Garay y Alaniz Limitada"; 11-X-1945, f. 540, núm. 245, "Compraventa: Barra y Cía. Limitada a Artuffo M., Esteban"; 26-VI-1944, f. 1336, núm. 443, "Compraventa: Sociedad Barra y Cía. Ltda. a Telman, José"; 28-IX-1944, f. 1344v, núm. 478, "Compraventa: Barra y Cía. Ltda. a Sánchez, José"; 9-IX-1944, f. 272v, núm. 145, "Compraventa: Sociedad Barra y Cía. Ltda. a Thut, Federico". 
siguientes. El Siglo fue eventualmente capaz de autofinanciarse y logró incluso ganar algo de dinero, el cual parece haber sido reinvertido en la misma empresa. ${ }^{13}$ Ahora bien, la capacidad que tenía el periódico para sufragar las deudas contraídas al momento de su formación no debe exagerarse. Los primeros años de vida del periódico estuvieron marcados por la precariedad, y las ganancias que llegó a producir nunca fueron realmente sustantivas. Las dificultades experimentadas durante los primeros años se hicieron patente en 1942, cuando el PCCH debió intervenir la administración del periódico y recapitalizar la Sociedad Barra y Compañía Limitada. ${ }^{14}$

Es también probable que Komintern haya ayudado a solventar algunos de los costos involucrados en la formación de El Siglo, ya sea proveyendo fondos para los pagos que se realizaron al contado o para el pago de los créditos. La ayuda financiera de Komintern al PCCH (y a tantos otros partidos comunistas alrededor del orbe) en los años treinta ha sido ampliamente demostrada (véase, v.gr., Klehr, Haynes y Anderson, 1998; Ulianova, 2005: 224-225 y 242-243; Ulianova y Fediakova, 1998). La documentación recopilada por Olga Ulianova y Alfredo Riquelme en los archivos rusos incluye no solo actas de reuniones e informes políticos sino también alguna que otra solicitud de dinero. Una de estas, que data de 1938, se titula "Proposiciones sobre prensa del Partido Comunista de Chile," y en ella se informa de la situación del periódico Frente Popular y de la imperiosa necesidad de aumentar su capital en $\$ 220.000$ : "Su capital pagado es de [\$]280.000 y necesitamos aumentarlo a quinientos mil pesos para mantener en nuestras manos el control de una Sociedad Anónima cuya formación hemos emprendido, la que contará con un capital de 1.000.000 de pesos chilenos" (citado en Ulianova y Riquelme, 2017: 469-470). Si bien la documentación recopilada por Ulianova y Riquelme no incluye nada similar para el caso de EI Siglo, creo que documentos como el citado arriba nos obligan a tomar en serio a quienes, sorprendidos por la adquisición de Moneda 716 y la buena factura del nuevo periódico comunista, apuntaban con el dedo acusador a la Unión Soviética. El hecho de que el PCCH haya optado por desmentir las acusaciones sobre el "oro de Moscú" haciendo referencia al dinero recaudado en colectas y campañas -el cual sabemos no alcanzaba a sufragar los empréstitos adquiridos-es también un indicio decidor (véase, v.gr., Escobar, 1939: 11; Qué Hubo, 21-XI-1939: 7; Qué Hubo, 16-III-1940: 8; Qué Hubo, 23-III-1940: 9).

13 Sobre esto, véase Federal Bureau of Investigation, 16-I-1945, "El Siglo", en NARA, Record Group 59, Decimal File 1945-49, Box 5355; Federal Bureau of Investigation, 17-XII-1946, "Financial organization of the Communist Party of Chile", en NARA, Record Group 59, Decimal File 1945-49, Box 5356.

14 Sobre esto, véase las siguientes escrituras públicas en AJS, notario Luis Azócar Álvarez: 27-VII-1942, f. 1924, núm. 521 "Modificación y prórroga Sociedad Barra y Cía. Ltda."; 27-VII-1942, f. 1928v, núm. 530, "Declaración: Pairoa, Amador y otros". 
La importancia del respaldo económico soviético y de las consideraciones internacionales en el funcionamiento de la prensa comunista nos obliga a discutir también un asunto poco conocido, a saber, el acceso del PCCH a créditos alemanes en los años iniciales de la Segunda Guerra Mundial. Nuestro conocimiento al respecto proviene de uno de los informantes del FBI, que destinó varios agentes a Chile en los años cuarenta. Según este informante, el Tratado de No Agresión Germano-Soviético, firmado en agosto de 1939 y conocido coloquialmente como Pacto Ribbentrop-Molotov, permitió que la prensa comunista recibiera créditos del Banco Alemán y del Banco Germánico, que operaban entonces en Chile. El primero de estos bancos, por ejemplo, habría abierto una línea de crédito de $\$ 500.000$ para que los comunistas chilenos adquirieran papel (un bien escaso, especialmente en los años de la guerra) de una empresa sueca. "La Fuente E -continúa el informe del FBIseñaló que en ese entonces el embajador Alemán en Chile también le instruyó a los encargados de los dos bancos alemanes antes mencionados, a través de [el agregado de prensa] Hammerschmidt, que le concediesen créditos ilimitados a El Siglo de ser necesario." El periodo de relaciones más o menos armoniosas entre la Alemania nazi y la Rusia soviética, que se extendió desde agosto de 1939 hasta la Operación Barbarroja, en junio de 1941, coincidió con un momento clave en la transición de Frente Popular a El Siglo, lo cual nos obliga a considerar la posibilidad de que créditos alemanes hayan jugado un rol en dicha transición. ${ }^{15}$

Antes de dar por finalizada esta primera sección sobre los orígenes de $E$ I Siglo, es menester señalar que la instalación del taller de imprenta de Moneda 716 no solo permitió la edición de esta publicación, sino también la de varias otras. Entre estas publicaciones, habría que incluir varias decenas de manifiestos, folletos y libros, la mayor parte de ellos de autoría comunista. Asimismo, en este taller de imprenta se editaron un número no menor de diarios, periódicos y revistas, además de El Siglo. Algunas de estas publicaciones periódicas, como es el caso de las revistas Principios, Mundo Nuevo y La Verdad de España, estaban vinculadas al PCCH. Otras, como es el caso de la revista deportiva Barra Brava o los diarios vespertinos Extra, La Tarde y Las Noticias de Última Hora, eran iniciativas de particulares, cuya producción le reportaban ingresos a la imprenta comunista (El Siglo, 31-VIII-1960: 13; El Pueblo, 16-VI-1946: 1 y 3; El Pueblo, 17-VI-1946: 5-6). Estos ingresos no deben haber sido despreciables. Sabemos, por ejemplo, que los trabajos para terceros realizados en los talleres de La Hora representaban alrededor de un 14\% de los ingresos del periódico radical (Couyoumdjian 1998: 28-29). Lo más probable es que los ingresos de El Siglo por esta vía hayan sido menores

15 Federal Bureau of Investigation, 16-I-1945, "El Siglo", en NARA, Record Group 59, Decimal File 1945-49, Box 5355. 
que los de La Hora, puesto que, para los administradores de la imprenta comunista, era común sopesar, conjuntamente, factores económicos y políticos al momento de tomar decisiones. Extra, La Tarde y Las Noticias de Última Hora, de hecho, tenían una línea de izquierda. Pero tal vez en ello radicaba la ventaja de tener una imprenta propia. Para un partido como el PCCH, interesado en granjearse aliados y adquirir mayor injerencia en la opinión pública, tener la capacidad de influir materialmente en el destino de otros actores de la izquierda chilena, era un activo valioso. ${ }^{16}$

Por último, cabe la pena señalar que la instalación de la nueva imprenta, en Moneda 716, permitió destinar la antigua a otras funciones. Originalmente, la idea parece haber sido enviar "a las Provincias la maquinaria que no sea utilizada," con el objeto de fortalecer la prensa regional del partido, que en ese entonces incluía lquique, Antofagasta y Concepción (citado en Ulianova y Riquelme, 2017: 470). Es probable que algunas máquinas hayan ido a parar a las provincias, pero la imprenta con la que antes se editaba Frente Popular no fue desmontada del todo. Como explicó Andrés Escobar ante el Comité Ejecutivo de Komintern, en marzo de 1941, la imprenta se mantuvo en Santiago, utilizándose "como taller de remiendas, con lo que se reúne algún dinero para ayudar a financiar nuestras publicaciones" (citado en Ulianova y Riquelme, 2017: 721).

\section{Muerte (y resurrección) de EI Siglo}

El comienzo del fin de El Siglo puede datarse en octubre de 1947. Las relaciones entre el PCCH y el entonces presidente de la República, Gabriel González Videla, habían venido empeorando desde hace meses, pero fue solo en octubre de aquel año cuando el Ejecutivo tomó medidas concretas para acallar las críticas de la prensa comunista y, posteriormente, ponerle freno al activismo comunista.

El 5 de ese mes, González Videla decretó que El Siglo quedara "sujeto a censura previa", como se lee en el decreto que lleva su firma, el cual fue reproducido por el diario en cuestión al día siguiente, en la página de portada (El Siglo, 6-X-1947: 1). La publicación de dicho decreto en la edición

16 Sobre esto, véase Federal Bureau of Investigation, 16-I-1945, "El Siglo", en NARA, Record Group 59, Decimal File 1945-49, Box 5355; Central Intelligence Agency, 4-IX-1947, "Reported Withdrawal of Communist Party Support from Newspaper Extra", General CIA Records, consultado en: https://www.cia.gov/library/readingroom/docs/CIA-RDP8200457R000800850009-5.pdf, revisado el 10-XI-2018; Central Intelligence Agency, 22-X-1947, "Suspension of Publication of Santiago Tabloid Newspaper Extra", General CIA Records, consultado en: https://www.cia.gov/library/readingroom/docs/ CIA-RDP8200457R001000270001-4.pdf, revisado el 10-XI-2018. 
del 6 de octubre es una de las pocas noticias sobre la censura que publicó El Siglo antes de su desaparición, a mediados del año siguiente, pues las autoridades que se hicieron cargo de la labor de censurar el periódico en los meses siguientes no dejaron que este informara de la censura a la cual estaba sometido. De hecho, la publicación del decreto llevó al reemplazo del censor nombrado por el Ejecutivo (Carlos Herrera López) y al nombramiento de un nuevo censor (Drago Vodanovic), el cual desde un comienzo parece haber utilizado un criterio más severo para evaluar qué podía y qué no podía ser publicado (El Siglo, 7-X-1947: 1).

El golpe más duro ocurrió unos días después, el 22 de octubre. En una acción coordinada, a lo ancho y largo del país, policías y agentes de investigaciones detuvieron a miles de dirigentes sindicales y militantes comunistas. El edificio de Moneda 716, donde se editaba El Siglo, fue uno de los primeros blancos de las fuerzas de orden. Alrededor de 200 carabineros y 100 agentes de investigaciones acordonaron el edificio en la madrugada, $y$, a las tres de la mañana, ingresaron armados, llevándose detenidos, "bala en boca, a todo el personal de reporteros, prensistas, linógrafos, fotograbadores, correctores de pruebas, periodistas de otras publicaciones que estaban presentes, y personal de portería" (El Siglo, 31-VIII-1960: 13). La decisión de ingresar al edificio por la madrugada no solo impidió que el periódico circulara aquel 22 de octubre, sino que permitió la captura de buena parte del personal técnico que laboraba en El Siglo, puesto que, como todo matutino, dependía de su trabajo nocturno para las labores de diagramación, compaginación e impresión. Varios de los detenidos esa noche terminaron relegados en Pisagua. A fines de noviembre, un periodista del diario les llevó "ayuda a 14 compañeros de El Siglo" que se encontraban allí (El Despertar, 1-XII-1947: 4). La mayor parte de los detenidos, sin embargo, parecen haber sido liberados poco después de su captura. El 25 de octubre, por ejemplo, fueron puestos en libertad 17 de los periodistas y operarios detenidos la madrugada del 22 de octubre, gracias a la acción del Círculo de Periodistas de Santiago y otras organizaciones de la sociedad civil (El Siglo, 26-X-1947).

El Siglo volvió a aparecer, bastante desmejorado, ese 25 de octubre, gracias al esfuerzo de un pequeño equipo de periodistas y obreros comprometidos con el proyecto político del diario. Sobrevivió a tientas varios meses, a pesar de que las posibilidades de informar de la actualidad política nacional se fueron restringiendo cada vez más. El censor "se dejaba caer por la imprenta pasada la medianoche, cuando ya el diario estaba compaginado," obligando al personal técnico a rearmar a toda prisa el ejemplar con el material que había pasado la censura (EI Siglo, 30-VIII-1970). El número de páginas del periódico disminuyó con el correr de los meses, bajando primero de ocho a seis y luego de seis a cuatro. Mientras tanto, la administración del diario siguió perdiendo colaboradores, pues "los agentes de la policía política permanecían apostados 
en las bocacalles y cada día o cada noche nos causaban una o dos bajas, llevándose a los linotipistas, compaginadores, prensistas o fotograbadores" (El Siglo, 31-VIII-1960: 13). La referencia al número de bajas es sin duda una exageración, pero sirve para hacerse una idea de la mentalidad de aquellos que decidieron seguir trabajando en el periódico, arriesgando su libertad.

Además de la censura y de la persecución contra el personal de la imprenta, una de las principales trabas que debió sortear E/ Siglo en sus últimos meses de vida fue la falta de metálico. Tras la arremetida gubernamental se acabaron los créditos bancarios y disminuyeron las empresas dispuestas a contratar publicidad en el periódico. Para hacer la situación aún más difícil, en los primeros meses de 1948 el Ejecutivo dispuso que una serie de instituciones públicas con las cuales la Sociedad Barra y Compañía Limitada había contraído préstamos en años anteriores (v.gr., el Instituto de Crédito Industrial y la Caja Nacional de Ahorros) recabasen la cancelación inmediata de dichas deudas. "En una ocasión, el Departamento de Periodistas de la Caja de EE. PP. y PP. dio un plazo de 48 horas para que se le cancelara una cuenta, bajo la amenaza de proceder a la incautación de la imprenta" (El Siglo, 31-VIII-1960: 13). El bien raíz más preciado del PCCH, el edificio de Moneda 716, sufrió múltiples embargos y medidas precautorias, las cuales la Sociedad Barra y Compañía Limitada logró cancelar tras la desaparición de El Siglo, entre septiembre y noviembre de 1948, con el objeto de vender el inmueble. ${ }^{17}$

La administración del periódico tuvo que hacer frente a los múltiples problemas económicos que acarreaba la censura tempranamente. Para obtener circulante y reducir los costos de producción, empezó a vender algunos de sus bienes a fines de 1947. El 17 de noviembre de aquel año, por ejemplo, la empresa vendió buena parte de su mobiliario (una gran cantidad de sillas, mesas y estantes, además de ocho máquinas de escribir) a Carlos Becerra Francino, del diario Las Noticias de Última Hora, por $\$ 100.000 .{ }^{18}$ Unos meses después, el 12 de abril de 1948, le vendió una máquina para imprimir diarios

17 Sobre esto, véase CBRS, Registro de Interdicciones y Prohibiciones de Enajenar del año 1948: f. 1610, núm. 3240, "Decreto anotado en el Repertorio con el No. 18593"; f. 1708, núm. 3246, "Decreto anotado en el Repertorio con el No. 19626"; f. 1708, núm. 3247, "Embargo anotado en el Repertorio con el No. 19665"; f. 1871, núm. 3732, "Decreto anotado en el Repertorio con el No. 21403"; f. 2425, núm. 4792, "Embargo anotado en el Repertorio con el No. 27398"; f. 2966, núm. 5928, "Embargo anotado en el Repertorio con el No. 31923"; f. 3576, núm. 7121, "Decreto anotado en el Repertorio con el No. 37513."

18 AJS, notario Luis Azócar Álvarez, 17-XI-1947, f. 716, núm. 295, "Compraventa y prenda: Soc. Barra y Compañía Ltda. a Becerra Francino, Carlos". Si bien el total de las especies transferidas estaba avaluado en $\$ 74.299,20$, la suma acordada le permitió a Becerra zanjar otras obligaciones que tenía con la Sociedad Barra y Compañía Limitada, pues, como explicamos arriba, esta empresa le prestaba servicios a diversos periódicos, entre la cuales figuraba Las Noticias de Última Hora. 
y un motor a la Sociedad Periodística El Llanquihue, por $\$ 380.000 .{ }^{19}$ El progresivo desmantelamiento de los talleres de El Siglo fue además estimulado por el traslado de una serie de máquinas (linotipias, prensas, etc.) a diversos puntos del país, con el objeto de utilizarlos en la impresión de periódicos y panfletos clandestinos, un tema que espero analizar con mayor detención en otro artículo.

El Siglo, antes económicamente rentable, sobrevivió a pulso hasta el 18 de julio de 1948. Al momento de desaparecer, el otrora glorioso vocero comunista se componía de solo cuatro páginas y casi no incluía publicidad. La decisión de no seguir publicando el diario, tomada por la administración del mismo, parece haberse visto influenciada por la coincidencia de los diversos factores adversos reseñados antes: la falta de personal técnico calificado, la acumulación de deudas, la falta de acceso a créditos, la imposibilidad de informar de la política contingente en los términos adecuados, entre otros. Da la impresión, sin embargo, que en última instancia los dirigentes del PCCH decidieron dejar de publicar El Siglo por considerarlo políticamente ineficaz, para concentrar de mejor manera sus esfuerzos en la edición de otros periódicos (El Pueblo primero, Democracia después), que fuesen capaces de sortear de mejor manera la censura gubernamental. Es difícil no interpretar esta decisión gerencial como la admisión de una derrota. Como recuerda una columna publicada en el trigésimo aniversario de El Siglo, varios años después de la reaparición del diario en 1952, "la tiranía había logrado silenciar esta publicación, aunque transitoriamente, sin ser acusada de emplear las herraduras" (EI Siglo, 31-VIII-1960: 13).

De igual o mayor relevancia que la decisión de no seguir publicando El Siglo fue la de disolver la otrora exitosa Sociedad Barra y Compañía Limitada y vender la propiedad de Moneda 716. Como explicamos, en el curso de unos pocos meses la Sociedad había dejado de ser económicamente rentable y la propiedad había quedado sujeta a múltiples embargos. El 25 de junio de 1948, los socios Carlos Contreras Labarca, Salvador Barra Woll y Andrés Escobar Díaz acordaron disolver anticipadamente la Sociedad y, tal vez temiendo ser detenidos y no poder efectuar personalmente la liquidación, nombraron liquidador al prestigioso abogado y profesor de derecho civil Enrique Rossel Saavedra, que no era comunista y tenía buenas relaciones con el radicalismo, quien debía actuar "con anuencia del abogado don René Frías Ojeda", comunista y otrora Intendente de Santiago. ${ }^{20}$ En el documento notarial que acordó disolver anticipadamente la Sociedad se dio plazo hasta

19 AJS, notario Luis Azócar Álvarez, 12-IV-1948, f. 534v, núm. 202, "Compraventa: Sociedad Barra y Cía. Ltda. a Sociedad Periodística El Llanquihue Ltda.".

20 AJS, notario Ernesto Almarza, 25-VI-1948, f. 1501, núm. 561 "Nombramiento de Árbitro: Sociedad Barra y Cía. Ltda.". 
el 1 de abril de 1949 para su liquidación, pues se entendía que la cancelación de las deudas pendientes y la venta de Moneda 716 podía tomar un tiempo.

No obstante dicho plazo, se vislumbraba la intención de la dirigencia comunista por vender el inmueble y disolver la Sociedad cuanto antes, para obtener liquidez y no seguir acumulando deudas. Este sentido de urgencia se vio reforzado por el temor a perder la propiedad, ya sea por deudas impagas o por el accionar del gobierno. Un informe de la CIA, del 15 de septiembre de 1948, señala que "el Presidente de Chile podría confiscar legalmente toda la propiedad de El Siglo bajo los términos de la Ley de Defensa," que había sido enviada al Congreso el 19 de abril de aquel año y que acababa de ser promulgada, el 3 de septiembre. El informe de la CIA advierte que era improbable que el gobierno tomara una medida tan drástica contra el PCCH, pues se le acusaría de actuar dictatorialmente. Pero sugería que el gobierno estaba intentando forzar la quiebra de la Sociedad y lograr así el remate de la propiedad y de la imprenta. El exministro del Interior, Alfonso Quintana Burgos, le había sugerido dicha estrategia a González Videla, y la decisión del gobierno de recabar la cancelación inmediata de las deudas que la Sociedad tenía con las instituciones públicas y semipúblicas mencionadas antes parece apuntar en ese sentido. De hecho, a mediados de septiembre de 1948, en el mismo momento en que el agente de la CIA escribía su informe, se publicaron avisos en la prensa capitalina anunciando "el remate público, para el 24 de septiembre, de ese insolente bastión comunista" (Estanquero, 18-IX-1948: 6).

No obstante el llamado a remate público, la Sociedad Barra y Compañía Limitada logró encontrar compradores para el inmueble de Moneda 716 antes de que este tuviera lugar. Los comunistas parecen haber encontrado fácilmente interesados, pues la propiedad estaba bien ubicada y había más de un interesado en ella. El mismo informe de la CIA, por ejemplo, señala que el abogado y dirigente del Partido Agrario Laborista, Jaime Larraín García-Moreno, había presentado una oferta de $\$ 6.000 .000$, la que no había sido aceptada, y que "el suegro de la hija del Presidente González Videla está formando una corporación para la compra del edificio de El Siglo con el objeto de convertirlo en un edificio de departamentos." 21 Sin embargo, ni Larraín García-Moreno ni el pariente político de González Videla lograron hacerse de la apetecida propiedad.

21 Central Intelligence Agency, 15-IX-1948, "Disposition of Property of El Siglo, Communist Newspaper," General CIA Records, consultado en: https://www.cia.gov/library/readingroom/ docs/CIA-RDP82-00457R001801030007-5.pdf. El informe no indica de qué hija de González Videla se trata, si de Rosa González Markmann, casada con José Claro Vial, o de Silvia González Markmann, casada con Alfonso Campos Menéndez. 
La Sociedad Barra y Compañía Limitada terminó frenando el remate público y vendiendo la propiedad a Sergio Alcayaga Tirapegui, Mario Larraín Acuña y los hermanos Jaime y Juan Luis Sanfuentes Yrarrázaval. El 21 de septiembre de 1948, tres días antes de la fecha en que el remate iba a tener lugar, la Sociedad firmó con todos ellos -y con José Lamas Deik, quien posteriormente se desistió de participar en el negocio- una promesa de compraventa estipulando los términos de la transacción en \$10.000.000. Gracias a esta promesa, recibió un adelanto de $\$ 2.000 .000$, fondos que, como indica el documento notarial, "sólo podrá destinar al pago de las obligaciones... que afectan al inmueble." 22 La Sociedad se comprometió a cancelar dichas obligaciones en un plazo máximo de cincuenta días, con el fin de realizar la compraventa, a más tardar, el 20 de noviembre. El principal obstáculo para la realización de la transacción dentro del plazo estipulado no provino, sin embargo, de parte de la Sociedad vendedora, sino de los compradores. Lamas, quien se había comprometido a cancelar el $60 \%$ de la compraventa, se echó para atrás un tiempo después de firmada la promesa, obligando a Alcayaga, Larraín y los hermanos Sanfuentes a conseguirse más dinero del que habían anticipado.

La transacción se celebró, finalmente, el 18 de noviembre de 1948. Ese día, la Sociedad Barra y Compañía Limitada transfirió la propiedad de Moneda 716 en $\$ 10.000 .000$ a Alcayaga, Larraín y los hermanos Sanfuentes. De esta suma, los compradores cancelaron $\$ 4.000 .000$ al contado, monto que incluía los $\$ 2.000 .000$ que habían cancelado por adelantado, al firmar la promesa de compraventa, el 21 de septiembre. Los compradores se hicieron cargo de dos deudas con la Caja de Crédito Propietario que gravaban al inmueble, las que sumaban $\$ 228.000$, y se comprometieron a pagar el saldo de $\$ 5.772 .000$ en dos cuotas, más intereses, en el plazo de 6 y 12 meses, quedando hipotecado el inmueble en garantía de dichos pagos. ${ }^{23}$ Los compradores tuvieron problemas para cumplir esta última parte del trato y no cancelaron las cuotas a tiempo. En abril de 1950, el Tercer Juzgado Civil de Mayor Cuantía de Santiago les embargó los derechos que les correspondían por la propiedad, a solicitud de la difunta Sociedad Barra y Compañía Limitada, en juicio por cobro de $\$ 5.772 .000 .{ }^{24}$ El embargo obligó a los nuevos dueños a cancelar parte del dinero, aunque no la totalidad de la deuda. En enero de 1951, cuando los dueños constituyeron una nueva sociedad comercial con el objeto de construir un nuevo edificio, reconocieron una deuda hipotecaria

22 AJS, notario Javier Echeverría Vial, 21-IX-1948, f. 1671, núm. 667, "Promesa de venta: Barra y Cía. Ltda. a Larraín A., Mario y otros".

23 AJS, notario Javier Echeverría Vial, 18-XI-1948, f. 1021, núm. 419, "Compraventa: Larraín A., Mario y otros a Barra y Cía. Ltda.".

24 CBRS, Registro de Interdicciones y Prohibiciones de Enajenar del año 1950, f. 1382, núm. 3253, "Embargo anotado en el Repertorio con el No. 14267". 
con la Sociedad Barra y Compañía Limitada, la que, incluyendo intereses, ascendía entonces a $\$ 2.329 .779,79.25$

La apresurada transferencia del edificio fue, en el decir de una publicación derechista de la época, "el fruto más tangible de la política anticomunista del Presidente González Videla" (Estanquero, 18-IX-1948: 6). El icónico inmueble de Moneda 716, que había servido de sede a la imprenta y al Comité Central del PCCH, fue demolido unos años después. En enero de 1951, los dueños de la propiedad -los ya mencionados Alcayaga, Larraín y los hermanos Sanfuentes- se asociaron con la Caja Bancaria de Pensiones, la Empresa Constructora Desco Limitada y otros inversionistas con el objeto de demoler la elegante casona de dos pisos y construir un moderno edificio de nueve pisos en su lugar. Bajo el nombre de Sociedad Edificio Moneda Limitada, constituida para dicho efecto, arrendaron y finalmente vendieron, una por una, decenas de propiedades individuales -departamentos residenciales y oficinas en los pisos de arriba, espacios para locales comerciales en el de abajo y estacionamientos y garajes en el subterráneo- durante los años siguientes, la mayor parte entre 1956 y $1965 .{ }^{26}$ Originalmente, se pensó denominar el nuevo inmueble Edificio El Siglo, aludiendo a su antigua función editorial, pero finalmente se optó por publicitarlo bajo el más inocuo nombre de Edificio Metropolitano, "para evitar que algunos compradores llegaran a relacionar al Partido Comunista con el nuevo edificio" (Ercilla, 16-X-1951: 3). ${ }^{27}$

En lo que respecta a la imprenta comunista, esta capeó el temporal y jugó un rol importante en la segunda etapa de El Siglo y en el funcionamiento de la Imprenta Horizonte, al menos hasta la importación de la famosa rotativa offset, en 1971, comprada, según cuenta la leyenda, con el dinero que obtuvo Pablo Neruda al ganar el Premio Nobel de Literatura. La azarosa existencia de la vieja imprenta de Moneda 716 entre la desaparición del periódico, en julio de 1948, y la reaparición del mismo, en octubre de 1952, merece ser reseñada con algún detalle. Como rememoró un artículo publicado en el periódico en cuestión, en 1960, el giro anticomunista de González Videla "puso también en peligro la rotativa, que vivió la penumbra de la persecución y muchas veces varias de sus piezas fueron a parar a los cuarteles de Investigaciones" (El Siglo, 31-VIII-1960: 8).

25 AJS, notario Rafael Zaldívar, 31-I-1951, f. 1451, núm. 540, "Formación: Sociedad Edificio Moneda Ltda".

26 CBRS, Registro de Propiedad del año 1951, f. 1451, núm. 2642, "Aporte: Mario Larraín y otros a Soc. Edificio Moneda Limitada"; AJS, notario Rafael Zaldívar, 31-I-1951, f. 1451, núm. 540, "Formación: Sociedad Edificio Moneda Ltda.".

27 Agradezco a Jorge Rojas Flores por facilitarme esta información sobre el nombre bajo el cual el edificio fue publicitado en la prensa de la época. 
La imprenta siguió operando en Moneda 716 tras la desaparición de El Siglo, en julio de 1948, aunque solo por unos meses. Entre septiembre y noviembre de 1948, imprimió El Pueblo, "órgano oficial del Frente Nacional Democrático", un periódico semi-legal, a través del cual el PCCH intentó hacer oír su voz durante el período más duro de la persecución. ${ }^{28}$ En noviembre de aquel año, sin embargo, empezó el desarme de la imprenta. La Sociedad Barra y Compañía Limitada acababa de vender la propiedad de Moneda 716, y la escritura de compraventa estipulaba que disponía de sesenta días para el retiro de la maquinaria. ${ }^{29}$

La operación de desarme, traslado y rearme de la imprenta consumió muchísimas energías. La tarea de desarme, "ejecutada bajo el sobresalto de las visitas policiales", tuvo lugar entre noviembre de 1948 y enero de 1949 (El Siglo, 31-VIII-1960: 8). El traslado fue igualmente complejo. Si bien el PCCH logró asegurarse la ayuda del famoso periodista Tancredo Pinochet Le-Brun, quien se comprometió a ceder un espacio y eventualmente a vender su propiedad de Lira 363, para la relocalización de la imprenta comunista, el traslado de la misma no ocurrió como los comunistas planeaban. Cuando los operarios de la imprenta llevaban las piezas de la maquinaria a la propiedad de Pinochet Le-Brun, en enero de 1949, fueron detenidos. Tanto los operarios como las piezas de la imprenta fueron a parar al cuartel de la Dirección General de Investigaciones, en General Mackenna 1314, donde permanecieron por algún tiempo. La imprenta solo volvió a entrar en funcionamiento el 23 de noviembre de 1950, tras haber sido rearmada, lentamente, pieza por pieza. Operó, desde entonces, y por muchos años, en Lira 363. Antes de la reaparición de EI Siglo, en octubre de 1952, fue utilizada para la impresión de otros periódicos, como Las Noticias de Última Hora y Las Noticias Gráficas. La edición de estos periódicos, de izquierda pero independientes, permitió al PCCH influir en la opinión pública y le reportó ingresos en un momento difícil.

Quisiera finalizar este apartado narrando, muy brevemente, la compra de Lira 363, donde se editó El Siglo durante su segunda etapa de vida y donde funcionó la icónica Imprenta Horizonte hasta el golpe militar de 1973. Pinochet Le-Brun vendió la propiedad al ingeniero Sergio Vial Salas, a través del cual el PCCH realizó la compra, por \$1.200.000, el 21 de junio de 1949, aunque la entrega material de la propiedad se había realizado un tiempo

28 El Pueblo había circulado, originalmente, y durante un corto tiempo, en junio de 1946, gracias a la ayuda de Tancredo Pinochet Le Brun y de su Imprenta Asíes, puesto que El Siglo había sido suspendido por cuatro días por atentar contra la seguridad interior del Estado y los comunistas no querían que su voz fuese acallada. La creación circunstancial de El Pueblo, en 1946, parece haber facilitado la circulación de un periódico cripto-comunista del mismo nombre, entre el 21-VIII-1948 y el 21-VIII-1949, periodo durante el cual se editaron 105 números.

29 AJS, notario Javier Echeverría Vial, 18-XI-1948, f. 1021, núm. 419, "Compraventa: Larraín A., Mario y otros a Barra y Cía. Ltda.". 
antes. ${ }^{30}$ La parte más sustancial de la transacción se realizó en efectivo, seguramente con el dinero que los comunistas habían obtenido de la venta de su anterior propiedad. El nuevo terreno adquirido era espacioso, de 75 metros de largo por 17 metros de ancho. Sobre este se erigía una casona vieja, bastante menos suntuosa que la de Moneda 716. Pinochet Le-Brun parece haberse decidido a vender porque el precio ofertado por los comunistas era conveniente (él había comprado la propiedad por $\$ 300.000$, en agosto de 1944, lo que reafirma lo dicho sobre el encarecimiento de los bienes raíces del centro de Santiago en estos años ${ }^{31}$ ) y porque quería liquidar la Sociedad Anónima Editorial Asiés, que ya no editaba la revista del mismo nombre, y que lo tenía enfrentado con sus accionistas. Pero, sin duda, facilitó la transacción el hecho de que, a lo largo de los años cuarenta, Pinochet Le-Brun había tejido una buena relación con los dirigentes comunistas y con los editores de El Siglo, periódico para el cual había escrito más de una columna.

En resumen, si bien la persecución anticomunista de González Videla llevó a la desaparición momentánea de El Siglo, el PCCH logró vender la propiedad de Moneda 716 a buen precio; comprar una nueva propiedad, en Lira 363, con una parte del dinero obtenido en dicha venta, y desmontar y trasladar la maquinaria del taller de imprenta, que al poco tiempo empezó a operar. En esta nueva propiedad, y con la misma rotativa, resucitó El Siglo en 1952.

\section{Conclusión}

Este artículo ha analizado la primera época de vida de E/ Siglo. A lo largo del mismo, espero haber demostrado que una comprensión adecuada del surgimiento y de la sobrevivencia de un periódico de esta naturaleza nos obliga a ir más allá del análisis de sus aspectos discursivos y políticos, que tanta atención han despertado en los estudiosos, y a indagar en sus condiciones de producción y en su gestión económica.

La formación de un periódico como El Siglo requería de una inversión inicial sustantiva. El periodismo moderno, que tomó fuerza en las primeras décadas del siglo veinte, era, al fin y al cabo, un negocio intensivo en capital, que premiaba a quienes estaban dispuestos a gastar sumas de dinero considerables en la adquisición de nuevas tecnologías y en la conformación de equipos periodísticos. En el caso de El Siglo, como he documentado en este artículo, el capital invertido en la compra de esas tecnologías y de un

30 AJS, notario Eliseo del Río Rondanelli, 21-VI-1949, f. 461, núm. 143, "Compraventa: Tancredo, Pinochet a Vial, Sergio".

31 AJS, notario Francisco Javier Hurtado, 4-VIII-1944, f. 175, núm. 78, "Compraventa: Groebe, Luis A. a Tancredo, Pinochet". 
inmueble para su funcionamiento parece haber sido del orden de $\$ 2.500 .000$ a $\$ 3.000 .000$. Mientras que el costo de las maquinarias del taller de imprenta parece haber bordeado el millón y medio de pesos, el precio del inmueble ubicado en Moneda 716 puede estimarse, con mayor grado de certitud, entre $\$ 965.000$ y $\$ 1.100 .000$.

Como se ha señalado en este artículo, el capital invertido provino de diversas fuentes: militantes comunistas, que colaboraron pagando sus cotizaciones regulares y aportando en campañas extraordinarias; miembros de otros partidos políticos, especialmente del Partido Radical, que buscaba fortalecer sus lazos con el comunismo; organismos públicos, como la Caja Nacional de Ahorros, cuya buena disposición a dar créditos a la Sociedad Barra y Compañía Limitada parece haberse visto influida por el entonces presidente de la República, Pedro Aguirre Cerda; y, muy probablemente, Komintern, que acostumbraba a financiar algunos de los gastos del PCCH durante aquellos años.

La desaparición de El Siglo en 1948 fue el resultado de diversos factores, entre los cuales vale la pena reiterar aquellos vinculados al aspecto económico del ataque de González Videla. La arremetida gubernamental disuadió a la mayor parte de las empresas de seguir contratando publicidad en el periódico comunista, dificultó el acceso a créditos bancarios y obligó a cancelar apresuradamente una serie de préstamos contraídos con anterioridad. Además, la imposibilidad de informar de la actualidad noticiosa en los términos deseados, debido a la censura previa, terminó por hacer de El Siglo un periódico poco útil para sus dueños y poco atractivo para los potenciales lectores, lo cual ayuda a explicar la decisión de la dirigencia comunista de abandonar, momentáneamente, dicho proyecto editorial.

Montar una empresa periodística es siempre un riesgo. Para un partido como el comunista, cuya línea política y editorial traspasaba frecuentemente los límites de lo permisible, el riesgo era aún mayor. Enfrentarse con las autoridades podía conllevar no solo hostigamientos y censuras, sino también multas y destrucción de maquinaria. El riesgo aumentó considerablemente a partir de octubre de 1947, cuando el fantasma de la quiebra se transformó en una amenaza real. Como he explicado en este artículo, el Gobierno de González Videla decidió no expropiar los bienes comunistas, para evitar ser acusado de actuar indebidamente, pero intentó forzar la quiebra de la Sociedad Barra y Compañía Limitada y el remate de Moneda 716 y de la imprenta comunista.

Sin embargo, la inversión inicial de los comunistas chilenos no se perdió. Gracias al compromiso político de algunos de los trabajadores del periódico, a la sagacidad de sus administradores $y$, en no menor medida, a la fortaleza del sistema democrático e institucional chileno, que impidió que González Videla diera rienda suelta a sus impulsos dictatoriales y se apropiara de los 
bienes del PCCH, los comunistas lograron salvaguardar la imprenta que habían adquirido años antes y vender el inmueble de Moneda 716 a buen precio. La venta de este bien raíz en $\$ 10.000 .000$ significó una sustantiva inyección de capital para el partido en un momento difícil, que le permitió comprar otra propiedad, en Lira 363, y financiar algunas de sus actividades en la clandestinidad. En efecto, los bienes de capital salvaguardados y el dinero líquido obtenido de esta venta jugaron un rol crucial en la sobrevivencia de la prensa comunista durante el gobierno de González Videla y, unos días antes de que este abandonara el cargo, en la reaparición de El Siglo.

\section{Referencias bibliográficas}

\section{Fuentes primarias}

a) Publicaciones periódicas

El Despertar, lquique, Chile, 1947.

El Popular, Santiago, Chile, 1946.

El Siglo, Santiago, Chile, 1940-1948, 1960, 1970.

Ercilla, Santiago, Chile, 1951.

Estanquero, Santiago, Chile, 1948.

Frente Popular, Santiago, Chile, 1939-1940.

Qué Hubo, Santiago, Chile, 1939-1940.

Vea, Santiago, Chile, 1939.

b) Impresos y libros

Escobar, A. (1939). Las finanzas del Partido: Problema político de vital importancia. Santiago: Ediciones del Comité Central del Partido Comunista.

González, G. (1938). El congreso de la victoria. Resumen de los informes, discusiones y resoluciones. Santiago: Antares.

Ravines, E. (1952). La gran estafa (la penetración del Kremlin en Iberoamérica). México: Libros y Revistas S.A.

Ulianova, O. y A. Riquelme A. (Editores) (2017). Chile en los archivos soviéticos, 1922-1991. Tomo 3: Komintern y Chile, 1936-1941. Santiago: Ediciones de la Dibam.

Varas, J. M. (2010). Los Tenaces. Santiago: Lom Ediciones. 


\section{c) Fuentes documentales}

Archivo Judicial de Santiago (AJS), Santiago, Chile.

Conservador de Bienes Raíces de Santiago (CBRS), Santiago, Chile.

National Archives and Records Administration (NARA), College Park, Estados Unidos.

\section{Fuentes secundarias}

a) Artículos y capítulos de libros

Acevedo, N. (2012). "La voz del campo. La política agraria del Partido Comunista de Chile durante el Frente Popular", en Izquierdas, № 13, pp. 63-82.

Bernedo, P. (2003). "La prensa escrita durante la Unidad Popular", en C. Rolle (Editor), 1973: La vida cotidiana en un año crucial. Santiago: Planeta.

Bernedo, P. y Arriagada, E. (2002). "Los inicios de El Mercurio de Santiago en el epistolario de Agustín Edwards Mac Clure (1899-1905)", en Historia, № 35, pp. 13-33.

Couyoumdjian, J. R. (1998). "La Hora, 1935-1951. Desarrollo institucional de un diario político", en Historia, № 31, pp. 5-56.

Dalmás, C. (2010). "Partidos comunistas e políticas culturais: Um estudo comparado da imprensa comunista no Brasil e no Chile, 1935-1956", en Izquierdas, № 8.

Donoso, K. (2016a). "Las mordazas a la prensa obrera: Los mecanismos de la censura política en chile, 1919-1925", en Izquierdas, № 28, pp. 191-225.

Donoso, K. (2016b). "'Los zarpazos del León.' La censura política contra la prensa en el segundo gobierno de Arturo Alessandri. Chile, 1933-1938", en Revista Tiempo Histórico Año 7, № 12, pp. 109-134.

Errázuriz, J. (2013). "La prensa obrera femenina y la construcción de la identidad de género", en Stuvens, A. y J. Fermandois (Editores) Historia de las mujeres en Chile. Tomo II. Santiago: Editorial Taurus.

Faure, A. (2017). " ¿Contribuyeron los medios de comunicación al golpe de Estado? Otra historia del periodismo durante la Unidad Popular (1970-1973)", en Izquierdas, №35, pp. 71-97.

Fernández-Niño, C. (2014). "Revista Ramona (1971-1973): 'Una revista lola que tomará los temas políticos tangencialmente", en Álvarez, R. y M. Loyola (Editores) Un trébol de cuatro hojas. Las Juventudes Comunistas de Chile en el siglo XX. Santiago: Ariadna Ediciones. 
López, A. (2016). "La Alborada y La Palanca. La narrativa feminista en la prensa obrera de mujeres. Chile, 1890-1915", en Historia Regional, Vol. 28, № 3, pp. 79-98.

Loyola, M. (2012). "Primera época de la revista Principios (1933-34) y la construcción del espacio intelectual marxista en Chile", en Izquierdas, № 13, pp. 29-46.

Moyano, C. y C. Rivera (en prensa). "Disputando lo político. La izquierda y la prensa política de masas en Chile, 1950-1989", en Universum. Revista de Humanidades y Ciencias Sociales.

Muñoz, V. (2015). "Cuando las bombas son de papel. Los trabajadores, el Estado y la propaganda anarquista impresa. Región chilena, 1915-1927", en Pacarina del Sur, Vol. 6, № 22.

Riquelme, A. (1986). "Trabajadores y pobladores en el discurso de la prensa sectorial popular. Chile, 1958-1973", en Documento de Trabajo, Santiago: Ceneca.

Rivas, F. (2012). "El Mercurio y la prensa obrera: Dos enfoques periodísticos para construir nación", en Correspondencias \& Análisis, № 3, pp. 249-262.

Rojas, J. (2012). "La prensa obrera chilena: El caso de La Federación Obrera y Justicia, 1921-1927", en Ulianova, O., M. Loyola y R. Álvarez (Editores) 1912-2012. El siglo de los comunistas chilenos. Santiago: Universidad de Santiago de Chile.

Salgado, A. (2018). "'El tribunal está abierto para críticas y para autocríticas': Luchas de poder y radicalización del Partido Comunista de Chile, 1945-1946", en Historia, Vol. 51, № 1, pp. 165-200.

Ulianova, O. (2005). "El PC chileno durante la dictadura de Ibáñez (1927-1931): Primera clandestinidad y 'bolchevización' estaliniana", en Ulianova, O. y A. Riquelme (Editores) Chile en los archivos soviéticos, 1922-1991. Tomo 1: Komintern y Chile, 1922-1931. Santiago: Ediciones de la Dibam.

Ulianova, O. y E. Fediakova (1998). "Algunos aspectos de la ayuda financiera del Partido Comunista de la URSS al comunismo chileno durante la Guerra Fría", en Estudios Públicos, № 72, pp. 113-148.

\section{b) Libros}

Couyoumdjian, J. R., E. Rozas y J. Tocornal (2002). La Hora, 1935-1951. Trayectoria de un diario político. Santiago: Ediciones Universidad Católica de Chile.

Dooner, P. (1989). Periodismo y política. La prensa politica en Chile, 1970-1973. Santiago: Andante.

Klehr, H., J. E. Haynes y K. Anderson (Editores) (1998). The Soviet World of American Communism. New Haven: Yale University Press. 
Ossandón, C. y E. Santa Cruz (2001). Entre las alas y el plomo. La gestación de la prensa moderna en Chile. Santiago: Lom Ediciones.

Ossandón, C. y E. Santa Cruz (2005). El estallido de las formas. Chile en los albores de la cultura de masas. Santiago: Lom Ediciones.

Santa Cruz, E. (2015). Prensa y sociedad en Chile, siglo XX. Santiago: Editorial Universitaria.

Sunkel, G. (2016). Razón y pasión en la prensa popular. Un estudio sobre cultura popular, cultura de masas y cultura política. Santiago: Ediciones y Publicaciones El Buen Aire S.A. 